\title{
Optimization of Hybrid Renewable Energy Power Systems: A Review
}

\author{
Binayak Bhandari', ${ }^{1,2}$ Kyung-Tae Lee ${ }^{1,2}$, Gil-Yong Lee ${ }^{3}$, Young-Man Cho ${ }^{2, \#}$, and Sung-Hoon Ahn ${ }^{1,2, \#}$ \\ 1 School of Mechanical \& Aerospace Engineering, Seoul National University, 1, Gwanak-ro, Gwanak-gu, Seoul, South Korea, 151-015 \\ 2 Institute of Advanced Machinery and Design, Seoul National University, 1, Gwanak-ro, Gwanak-gu, Seoul, South Korea, 151-015 \\ 3 William E. Boeing Department of Aeronautics and Astronautics, University of Washington, Seattle, WA, 98195, USA \\ \# Corresponding Author / E-mail: ahnsh@snu.ac.kr, TEL: +82-2-880-7110, FAX: +82-2-888-9073 \\ E-mail: ymcho85@hotmail.com, TEL: +82-2-880-9073, FAX: +82-2-888-9073
}

KEYWORDS: Hybrid renewable energy systems, Optimization, Mathematical modeling, Photovoltaic(PV), Wind, Hydro

\begin{abstract}
The characteristics of power produced from photovoltaic (PV) and Wind systems are based on the weather condition. Both the system are very unreliable in itself without sufficient capacity storage devices like batteries or back-up system like conventional engine generators. The reliability of the system significantly increases when two systems are hybridized with the provision of storage device. Even in such case, sufficient battery bank capacity is required to provide power to the load in extended cloudy days and non-windy days. Therefore the optimal sizing of system component represents the important part of hybrid power system. This paper summarizes recent trends of energy usage from renewable sources. It discusses physical modeling of renewable energy systems, several methodologies and criteria for optimization of the Hybrid Renewable Energy System (HRES). HRES is getting popular in the present scenario of energy and environmental crises. In this paper, we present a comprehensive review on the current state of optimization techniques specifically suited for the small and isolated power system based on the published literatures. The recent trend in optimization in the field of hybrid renewable energy system shows that artificial intelligence may provide good optimization of system without extensive long term weather data.
\end{abstract}

Manuscript received: November 1, 2014 / Revised: December 4, 2014 / Accepted: December 7, 2014 (Invited Paper)

\section{Introduction}

Fossil fuels like coal, oil and natural gas are currently the world's primary energy sources. The heavy dependence on the fossil fuel in $20^{\text {th }}$ century largely reduced the natural reserve of it. Aware of its finite reserve and adverse effect on environment, engineers and scientists are increasingly trying to find and use alternative energy sources. The three most widely used renewable alternative energy sources are hydro, wind and photovoltaic (PV).

For isolated and remote places where chances of reaching national grid is minimum because of technical and economic constraints, renewable energy system is considered as an attractive alternative and thus preferred in many regions and countries. Such power system can be PV, wind and hydro or the combination of them. Such system can also have backup devices like diesel generator and battery bank to meet peak hour demand. Table 1 lists some characteristics of renewable energy power system (REPS).

Electric power is vital for both economic and personal well-being. A well-engineered renewable energy system can be cost effective, highly reliable and can improve the quality of life. ${ }^{1}$ In most cases, solar and wind energy complement each other, however both are unpredictable because of instantaneous fluctuation of solar irradiation and wind speed. A new hybrid system comprising of solar-wind and hydro were implemented by Bhandari et al. ${ }^{2,3}$ in the remote village of Nepal. Ahn et al. ${ }^{4}$ explored the characteristics of an off-grid hybrid renewable energy system (HRES) and their implications regarding the reliability of the system.

HRES is largely dependent on its components, thus an accurate

Table 1 Characteristics of REPS

\begin{tabular}{cc}
\hline Advantages & Disadvantages \\
\hline $\begin{array}{c}\text { Use free resources } \\
\text { like the sun } \\
\text { and wind for fuel }\end{array}$ & $\begin{array}{c}\text { Renewable energy production is } \\
\text { dependent on natural cycles }\end{array}$ \\
\hline $\begin{array}{c}\text { Operation and } \\
\text { maintenance } \\
\text { requirements are low } \\
\text { No problem of } \\
\text { pollution or waste } \\
\text { natural resources }\end{array}$ & $\begin{array}{c}\text { Initial cost of these systems are higher than } \\
\text { comparably sized conventional generators }\end{array}$ \\
\hline
\end{tabular}


modeling of each component of HRES provides tools to better understand the performance and reliability of the system, assisting to optimize HRES. The present paper comprehensively reviews the various optimum sizing methods and optimization criteria of hybrid power system based on small PV, wind, hydro and storage devices. For a clear understanding, tables have been provided for various optimization techniques and optimal designs. Mathematical models, figures and flow charts have also been provided wherever necessary. The paper will also discuss on the recent trend of world energy scenario, and development on curbing the energy demand of future with relevant references throughout this paper.

\section{World Energy Scenario}

World energy consumption is growing about $2.3 \%$ per year according to Energy Information Administration. ${ }^{5}$ In Denmark, wind generates about 20 percent of all electricity. Globally, wind supplies less than one percent of electric power, but it is the fastest growing energy source.

It is expected that the world's energy consumption is grown by $53 \%$ from 2008 to $2035 .^{5}$ Fig. 1 shows the strong growth of the global energy demand.

In Fig. 2, the US's electricity generation by fuel is shown from 1990 to 2040. It can be seen that however renewable share will increase by few percent, fossil fuels like coal and natural gas still dominates.

The global economy growth is highly dependent on whether the

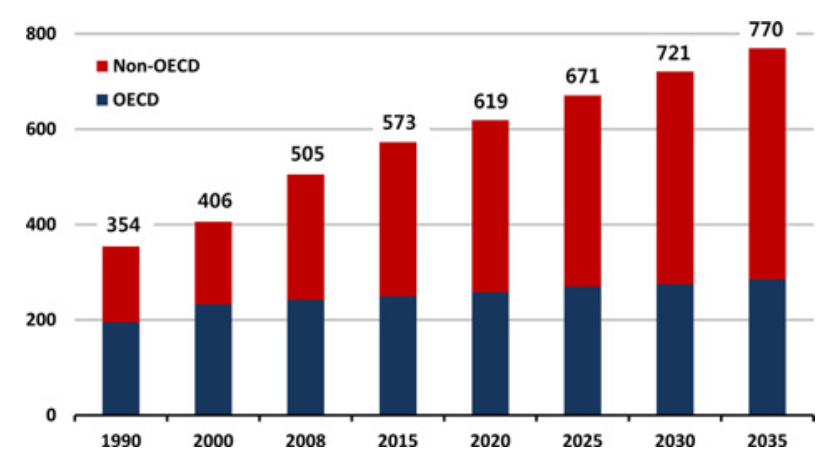

Fig. 1 World energy consumption, 1990-2035 (quadrillion Btu) (reused from ref. 5 with permission)

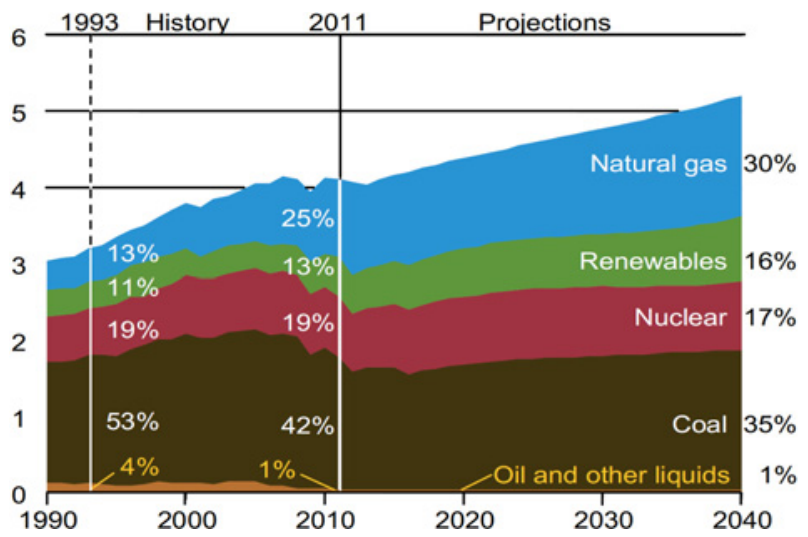

Fig. 2 US electricity generation by fuel, 1990-2040 (trillion kilowatthours per year) (reused from ref. 6 with permission) increasing energy demand can be met or not. Fossil fuels are not evenly distributed around the world, and regional or global conflicts may arise from energy crisis if global economy heavily depends on them. Using today's conventional fuels, the global environment has been adversely affected and the environment of some regions has been damaged severely. This forces us to figure out the new techniques to harness needed amount of energy. ${ }^{7}$ In Fig. 3, energy generation in the US by various sources is shown.

Global demand for renewable energy continued to rise during 2011 and 2012, supplying an estimated $19 \%$ of global final energy consumption in 2011. Other renewable energy (except hydropower) grew $21.5 \%$ in 2012 to exceed $480 \mathrm{GW}$. Globally, wind power accounted about $39 \%$ of renewable power capacity in 2012 , followed by hydropower and solar PV, each accounting for approximately $26 \%$. PV global operating capacity surpassed 100GW in 2012. ${ }^{9}$ In 2011 and 2012, wind power added more capacity than any other renewable energy. ${ }^{10}$ Fig. 4 shows the existing world capacity of PV and wind.

An estimated $30 \mathrm{GW}$ of new hydropower capacity was added in

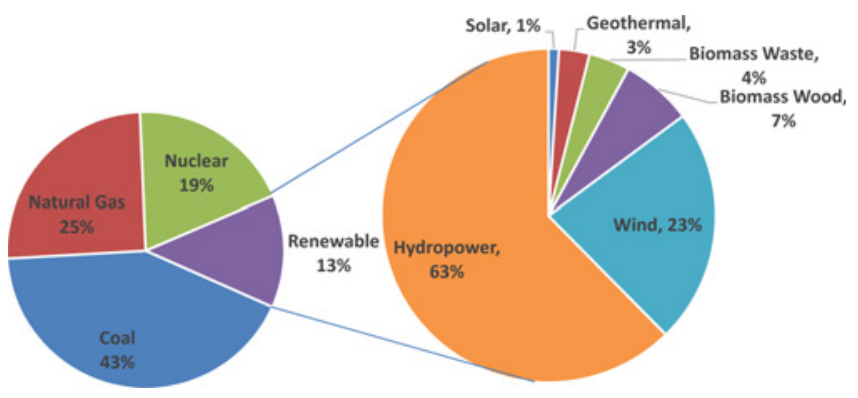

Fig. 3 Energy sources in the US (drawn using data from ref. 8)

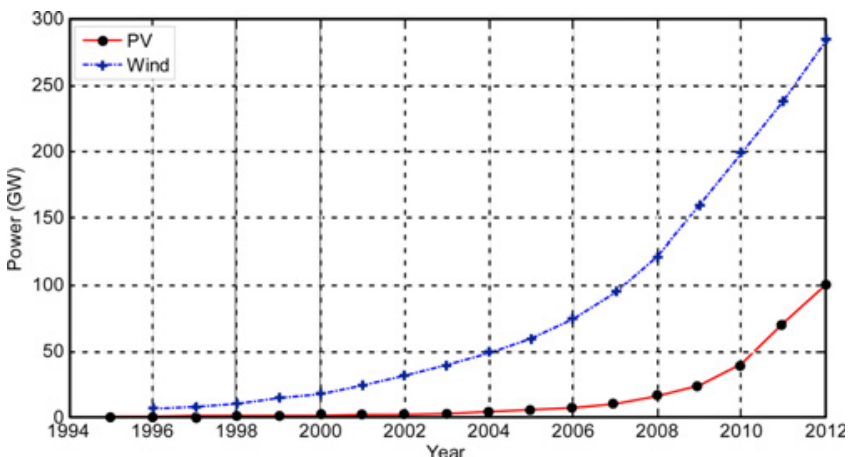

Fig. 4 Wind power and PV power, existing world capacity (19962012) (drawn using data from ref. 11)

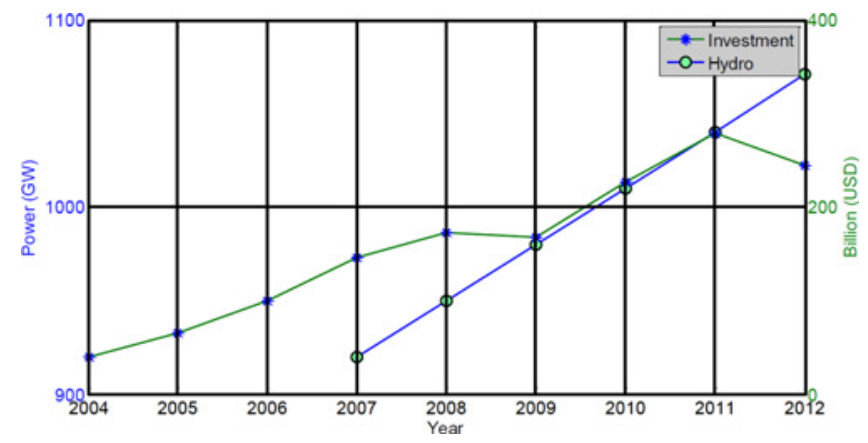

Fig. 5 Existing hydro power capacity (2007-2012) and investment in renewable energies (2004-2012) (drawn using data from ref. 11) 
2013, which is about $3 \%$ to an existing capacity. The investment in renewable energy has been constantly rising except in the year 2012, which is because of reduction in subsidies for wind and solar project development in Europe and the US and falling technology cost of PV and wind power. Fig. 5 shows the global investment in renewable energies and the existing hydropower capacity.

\section{Types of Small Power System}

Small power systems are mostly used for providing power to isolated and rural areas. Increase in mini-grids has risen parallel with price reductions in solar, wind and inverter technologies. Depending on the connection of power systems to the main grid, small power systems can be broadly classified into grid-tied system and off-grid power systems. Fig. 6 shows each type of power systems in detail.

\subsection{Off-Grid Systems (Stand-Alone System)}

Almost all the small power systems that are designed and optimized to meet the power demand of remote places are off-grid power systems. An off-grid systems does not have a connection to the main electricity grid. Standalone systems vary widely in size and application from wristwatches or calculators to remote building or spacecraft.

\subsection{Grid Tied Systems}

A grid connected system is connected to a larger independent grid typically the public electricity gird ${ }^{12}$ and feeds energy directly into the grid. The feeding of electricity into the grid requires the transformation of DC into AC by a synchronizing grid-tie inverter (also called gridinteractive inverter).

\section{Hybrid Power Systems}

Hybrid power systems are designed for the generation of electrical power using number of power generation devices such as wind turbine, $\mathrm{PV}$, micro hydro and/or other conventional generators using fossil fuels. Such systems can range from small system capable for providing power for a single home to large system which can power a village or an island. Hybrid power systems are thought to provide power to many remote communities especially in the developing world where the national grid is economically and technically not viable.

\subsection{Photovoltaic System}

Solar photovoltaic is now, after hydro and wind power, the third most important renewable energy source in terms of globally installed

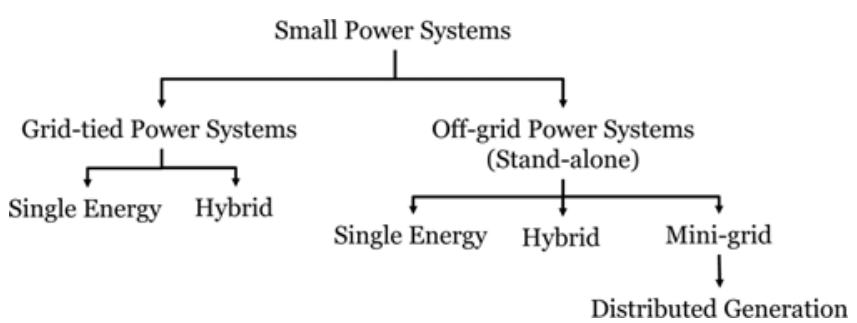

Fig. 6 Classification of small power systems based on grid connection capacity. Solar panels convert solar energy from the sun directly into useable electrical energy. The world's largest individual PV power plants are Agua Caliente Solar Project (Arizona, USA) and California Valley Solar Ranch (USA). Both power plant produces more than $250 \mathrm{MW}_{\mathrm{P}}{ }^{13,14}$ However because cost of solar panels are still high, their use are limited to less than 1 percent of electricity generation worldwide.

Because it cannot produce energy round the clock, there is always the need of storage devices like battery bank. Among systems installed in 2011 , the median reported price was $\$ 6.13 / \mathrm{W}$ for residential and small commercial systems up to $10 \mathrm{~kW}$, and $\$ 4.87 / \mathrm{W}$ for commercial systems larger than $100 \mathrm{~kW}$ as shows in Fig. $7 .^{15}$

PV energy systems are termed as one of the cost effective solutions to meet energy requirements of remote areas. Economic viability of hybrid PV system for decentralized power generation has been carried out and has proved its usefulness for small villages with up to 100 families. ${ }^{16}$ Muselli et al. ${ }^{17}$ studied on the system sizing of PV-hybrid system including a back-up conventional diesel generator. The starting and stopping thresholds of back-up generator were calculated with respect to battery nominal storage capacity. El-Hefnawi ${ }^{18}$ used a mathematical technique using FORTRAN programming language to calculate minimum number of storage days and PV array area taking in consideration of pre-operating time of the diesel-generator for hybrid PV system. Shrestha and Goel ${ }^{19}$ demonstrated a method to find optimal combination of PV array size and battery to meet the load. The load and insolation was found out using statistical models.

A closed form solution approach to the problem of evaluating loss of power supply probability (LPSP) of standalone PV battery hybrid system was proposed by Abouzahr \& Ramakumar. ${ }^{20}$ In iterative optimization technique of hybrid PV system, optimal mix can be decided on the basis of cost of electricity generated which is further justified on the basis of extension from the nearest power line, the tilt and azimuth angle. Performance of hybrid PV system is evaluated on the basis of reliability of power supply under widely varying load conditions. Egido and Lorenzo ${ }^{21}$ reviewed methods for computing capacity of PV arrays and battery storage and suggested analytical model based on loss of load probability (LOLP). Ru et al. ${ }^{22}$ determined the battery bank storage capacity in grid-connected PV system.

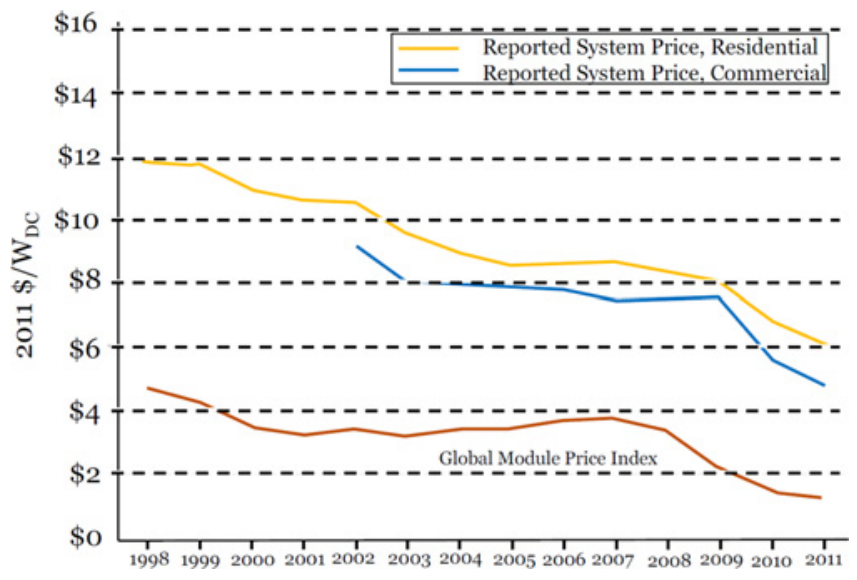

Fig. 7 U.S. PV system price over time (redrawn and used from ref. 15 with permission) 


\subsection{Wind System}

Since early recorded history, people have been harnessing the energy of the wind. Earlier use of wind power were to propel the boat, pumping water or grinding grain. The first windmill used for the production of electricity was built in Scotland in July 1887 by Prof James Blyth of Anderson's College, Glasgow. Later in the winter of the same year Charles Brush was also credited with being the first person to use a wind powered machine to generate electricity in the US. ${ }^{23}$

In order to use hybrid wind energy system effectively and economically, chosen site should have good potential of wind energy throughout the year. At present, wind power is harnessed with small and large wind turbines of various types and configurations. It is one of the fastest growing alternative energy source. Unlike solar power, it has longer operating time and can produce powers during cloudy days and night.

Europe alone produces about $35,000 \mathrm{MW}$ of electricity using wind power. The limitation is that, when wind does not blow, these wind turbines do not produce power. During such time to meet the demand other power sources are needed. Hence both wind and solar needs a storage devices to store surplus energy and use it when there is not enough power produced to meet the demand. In contrast, the comforting prospect is that people can generate their own energy to meet their daily energy demand by installing small solar and/or wind farm.

Feijoo et al. ${ }^{24}$ used wind speed distribution (Rayleigh) and found out its impact on wind farms using Monte Carlo simulation. Li et al. ${ }^{25}$ used regression and artificial neural network models for the estimation of wind turbine power curves. Salameh and Safari ${ }^{26}$ studied the effect of the windmill's parameters on the capacity factor based on long term wind speed data. Capacity factor of wind turbine is one of the deciding parameters to choose a particular type of wind turbine at the selected site, as an essential component of hybrid wind system. The windmill with the highest average capacity factor has been recommended wherever possible. Boccard ${ }^{27}$ studied the discrepancy of realized values and estimates of capacity factors. Celik ${ }^{28,29}$ proposed a simplified algorithm to estimate yearly wind fraction based on the simulation results of 8 year, hour-by-hour wind speed data of five different locations. The method requires Weibull wind speed distribution parameters on a monthly basis, the energy to load ratio and battery to load ratio and some model parameters as input.

A closed form solution approach for evaluating LPSP of stand-alone wind system with energy storage device was presented by Abouzahr \& Ramakumar. ${ }^{30}$ Karki and Billinton ${ }^{31}$ presented a simulation technique generating probability indices using Monte Carlo simulation approach which helped determine appropriate wind power penetration in an existing power system considering economic and reliability aspect.

\subsection{Hydro System}

Water wheels are the predecessor of modern day turbine used to convert the hydraulic power into mechanical power and further into electrical power using generator. The evolution of the modern hydropower turbine began in the mid-1700s when a French hydraulic and military engineer, Bernard Forest de Bélidor wrote Architecture Hydraulique. ${ }^{32}$ In 1880 , a brush arc light dynamo driven by a water turbine was used to provide theatre and storefront lighting in Grand
Rapids, Michigan; and in 1881, a brush dynamo connected to a turbine provided street lighting at Niagara Falls, New York. These two projects used direct-current technology. The world's first hydroelectric plant (1882) is located in Appleton, Wisconsin, which produces $12.5 \mathrm{~kW}$.

World hydroelectric power generation has risen steadily by an average of 3 percent annually over the past four decades. In 2011, roughly 16 percent of global electricity has been provided by hydropower from over 160 countries. Countries like Norway, Paraguay, Ethiopia, Venezuela, Bhutan and Nepal get the greatest share of their electricity from hydropower. ${ }^{33}$

Unlike unpredictable and rapidly fluctuating solar and wind power, hydro power has a long seasonal cycle. The water flowing in the rivers and streams change slowly according to seasons of the year. Hence the need of energy storage device is not required. It was the most widely used form of renewable energy, accounting for 16 percent of global electricity generation in $2010 .{ }^{34}$

\subsection{Hybrid Renewable Energy System (HRES)}

The first village hybrid power systems consisting of PV and diesel generator was installed on December 16, 1978 in Papago Indian Village, Schuchuli, Arizona, USA. The power produced by the system was used for providing electricity for community refrigerator, washing machine, sewing machine, water pumps and lights until an electric grid was extended to the village in $1983 .{ }^{35}$

In recent years, more than one renewable form of energy are being used in HRES. Micro hydro power (MHP), PV and small Wind power sources with or without energy storage devices are widely used for providing electric power to consumers in remote areas. Different alternative energy resources have different production characteristics such as, water in river changes flow according to the seasons, the solar irradiation is greater in summer than winter and higher in day and non at night and similarly wind speed is greater in summer etc. This is why they are usually used in hybrid system configurations.

The advantages of the HRES are as follow:

- Two or more renewable energy sources can be integrated in one system, based on the local renewable energy potential

- No any form of emission is produced from all renewable energy hybrid system (like PV, Wind and Hydro integrated)

- Modular (PV and wind system) are easy to install and in most case needs no design for domestic use.

- Smaller hybrid systems are cheaper than larger and complex systems like nuclear system.

- Small hybrid system is best suited for off-grid electrification

- Fuel for HRES is abundant, free and inexhaustible hence electric energy produced by these system is independent of fuel price

Standalone commercial PV or wind systems do not produce power round the clock and throughout the year. Combining PV and wind has the benefit of reduced battery bank capacity and diesel requirements (in case it has conventional generator as back up) among other benefits. However, for better performance of hybrid PV-Wind system, good potential of solar irradiation as well as wind energy is a must at the site. Factors like environmental factors, PV capacity (the number of PV panel), wind generator capacity (the size of wind generator), storage device capacity (the number of battery), generation site (distance between power plant and consumer), etc. play an important role in 
operation, maintenance and cost of the hybrid PV/wind - diesel system.

Nehrir et al., ${ }^{36}$ reported the evaluation of general performance of stand-alone hybrid PV/wind system using computer-modeling approach (MATLAB/Simulink).

$\mathrm{Lim}^{37}$ presented a method to design the optimal combination and unit sizing for wind-PV and tide hybrid system. Notton et al., ${ }^{38}$ presented a mathematical model for sizing hybrid PV system on the basis of LOLP. The authors have highlighted that the optimal solution can be obtained if $\mathrm{PV}$ contributed for $75 \%$ of the energy requirements. Elhadidy and Shaahid ${ }^{39}$ analyzed hybrid system consisting PV, wind, diesel generator with battery backup in hybrid energy system. They studied the impact of variation of PV array area, number of wind generator and battery storage capacity of HRES.

Chedid et al. ${ }^{40}$ proposed decision support technique for policy maker about the influencing factors in the design of grid linked hybrid $\mathrm{PV}$-wind power system. They used analytic hierarchy process (AHP) to quantify various parameters that lead to confusion in planning hybrid system. Their study was based on political, social, technical, and economical issues.

The block diagram of a stand-alone hybrid MHP-PV-WG is shown

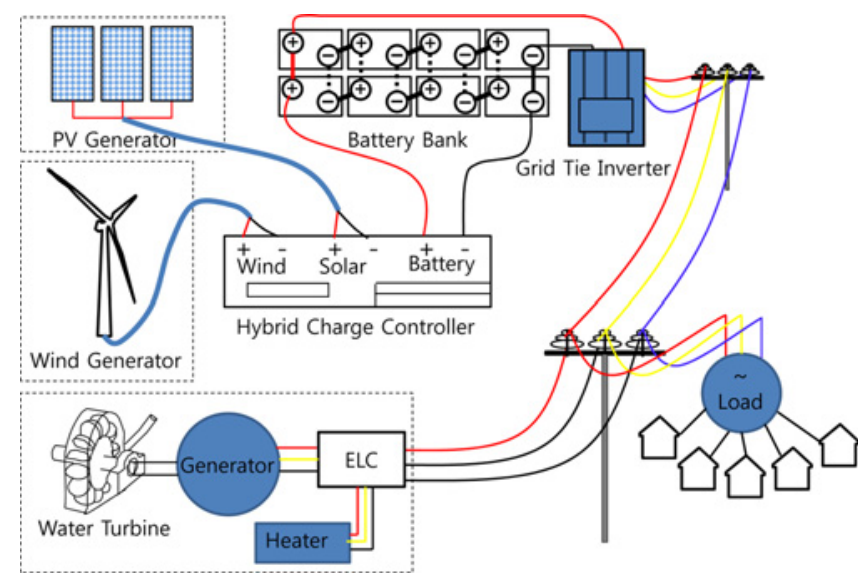

Fig. 8 Schematic diagram of typical hybrid micro hydro power (MHP)-PV-Wind systems in Fig. 8. A hybrid charge controller is used to connect two power sources (PV-WG). Depending on the load the excess power is used to charge the battery bank. The battery bank is used to store the surplus energy and to supply the power to the load in case of insufficient power generation from the hybrid system. The inverter (DC/AC) is required to change the DC voltage to AC voltage to meet the consumer load demand. The outputs of all battery chargers, the battery bank and the DC/AC converter input terminals are connected in parallel. The instantaneous change in solar irradiation and wind speed characteristics highly influences the energy production thus a careful design is needed for hybrid system for reliable power supply to the consumers under varying atmospheric condition. In the same way a careful design should be made to keep the system cost low.

\subsection{Future of Hybrid Renewable Energy Systems}

Over 1 billion people still lack access to electricity. The United Nations General Assembly declared the decade 2014-2024 as the Decade of Sustainable Energy for All, underscoring the importance of energy issues for sustainable development and for the elaboration of the post-2015 development agenda. ${ }^{41}$

In a distributed hybrid systems, power is produced at or close to the point of use. Distributed energy systems avoid the costs and losses of transmission and distribution. Therefore, there is need to identify locations for installing PV and wind energy systems and their interconnections with the utility grid, in order to minimize the cost of electricity without disturbing the existing network.

Renewables play a major role in the energy demand in many countries around the world. In recent years, prices of renewable energy technologies, primarily wind and solar continues to fall, making renewable increasingly competitive with the other conventional energy technologies.

Two most important concerns for any hybrid systems are the system's power reliability during varying environmental condition and the overall cost of the system. Most of the authors tried to optimize either or both of it. A detail bubble diagram of the scope of the paper is shown in Fig. 9.

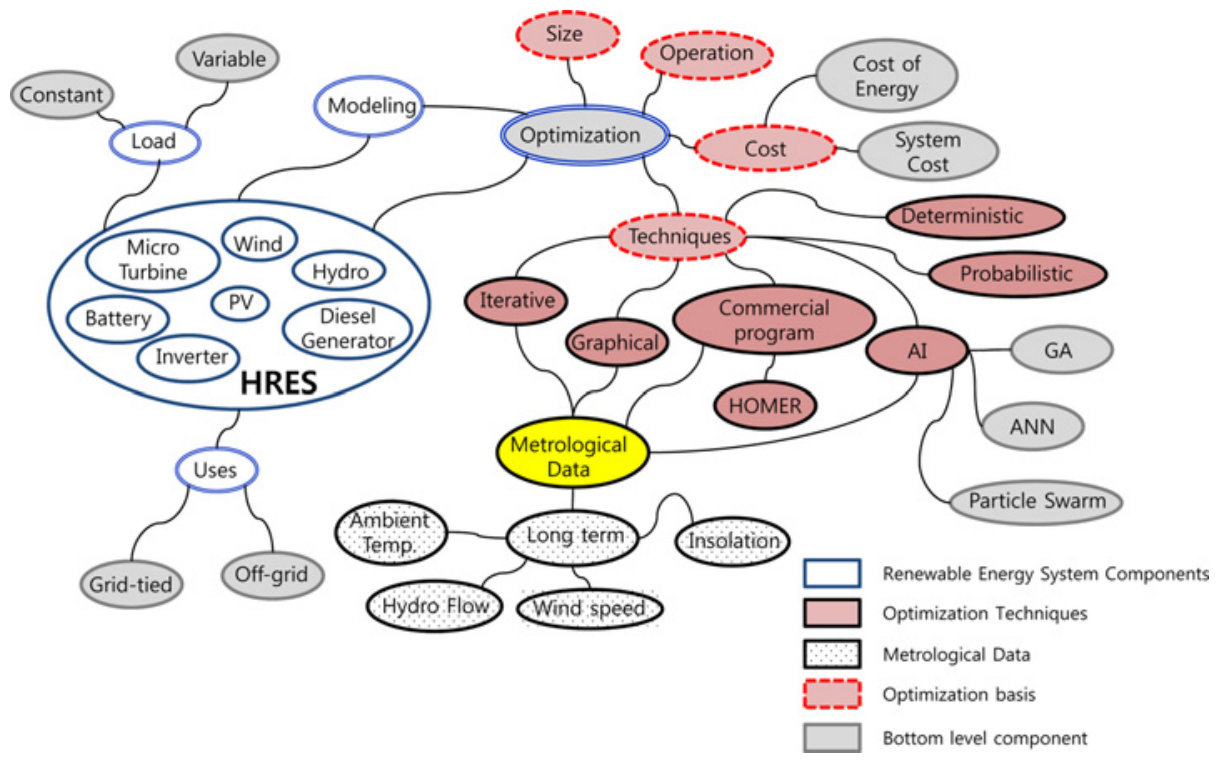

Fig. 9 A scope diagram showing the coverage of this review paper 


\section{Mathematical Modeling}

A hybrid power generation system might consist of renewable energy conversion system like wind turbine, PV array, hydro turbine, fuel cells and other conventional generator like diesel generator, micro turbine and storage devices like battery. A hybrid power system might consist all or part of it. To accurately size the individual components of the system, simulation of the system under real operating condition like appropriate weather, insolation, wind speed and loads is necessary. The components and subsystems of a HRES are interconnected to optimize the whole system. The design of a hybrid system will depend on several requirements like location, standalone or grid tied, DC or AC load etc.

Usually, most of distributed hybrid systems are designed to supply power to houses or small community for basic electrical use like elementary lighting, radio and televisions, small domestic electrical appliances, street lighting, etc.

While HRES consists strictly of renewable energies only. The main objective in case of HRES is to utilize maximum proportion of renewable energy, other factors includes the financial investment, reliability and durability.

The first step in optimization of hybrid system performance is the modeling of individual components. Bhandari et al. ${ }^{42}$ provided comprehensive mathematical modeling of HRES comprising of small hydro-solar and wind power systems. Modeling process enables to recognize and improve understanding of a situation, identify the problem and support the decision making. The details of modeling are reflected by its correct prediction of performance, however it is too complex or extremely time consuming to design a perfect model. A sufficiently appropriate model should be tradeoff between complexity and accuracy. Performance of individual component is either modeled by deterministic or probabilistic approaches. ${ }^{43}$ General methodology for modeling HRES like PV, wind, diesel generator and battery are described below:

\subsection{PV Array Modeling}

The most common model used to predict energy production in PV cell modeling is the single diode circuit model shown in Fig. 10. ${ }^{44-46}$ Single-diode PV cell model without shunt resistance is known as ideal single-diode model (ISDM).

Depending on the availability of shunt resistance $\left(R_{s h}\right)$, the output current in the single diode PV cell model can be modeled using equations 1,2 and 3. However two-diode PV cell is also common. Salam et al. ${ }^{47}$ utilized two-diode PV model to represent PV cell.

$$
\begin{gathered}
I=I_{p h}-I_{0}\left(\exp \left(\frac{V+R_{S} I}{A}\right)-1\right)-\frac{V+R_{S} I}{R_{s h}} \\
I=I_{p h}-I_{0}\left(\exp \left(\frac{q V}{k T}\right)-1\right)
\end{gathered}
$$

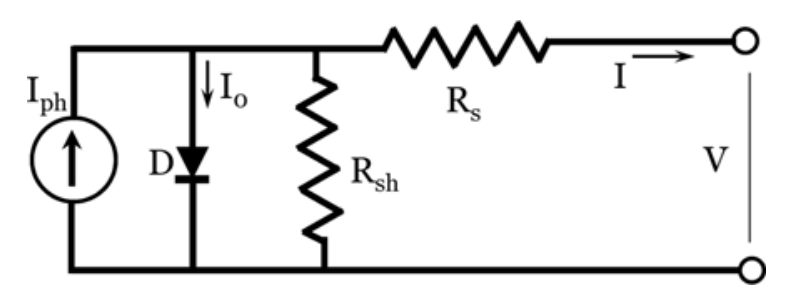

Fig. 10 A single diode PV cell model

$$
A=\frac{N_{S} n k T_{c}}{q}
$$

where $I$ is output current (A), $I_{0}$ is inverse saturation current which depends on temperature, $I_{p h}$ is photocurrent (A) which depends on solar radiation and cell temperature, $V$ is output voltage, $R_{s}$ is series resistance, $k$ is the Boltzmann constant, $q$ is electron charge $\left(1.6 \times 10^{-19}\right.$ C), $T_{c}$ is the cell temperature, $n$ is the usual ideality factor, and $N_{s}$ is the number of cells in series. The power produced by the PV is the product of the current and voltage.

The input energy to the PV system is normal and diffuse solar radiation which depends on position of sun in the sky and the time of the year. Equation 4 can be used to find the total radiation on the solar cell.

$$
I_{T}=I_{b} R_{b}+I_{d} R_{d}+\left(I_{b}+I_{d}\right) R_{r}
$$

where $I_{b}$ is normal radiations, and $I_{d}$ is diffuse solar radiation, $R_{d}$ is the tilt diffuse factor and $R_{r}$ is tilt factor for reflected solar radiations. ${ }^{48}$

Hourly power output from PV system $P_{s j}(\mathrm{~kW})$ with an area $A_{p v}$ $\left(\mathrm{m}^{2}\right)$ on an average day of $j^{\text {th }}$ month is given by equation $5,{ }^{49}$ when total solar radiation of $I_{T j}\left(\mathrm{~kW} / \mathrm{m}^{2}\right)$ is incident on the PV surface.

$$
P_{s j}=I_{T j} \eta A_{P V}
$$

where system efficiency $\eta$ is given by equation $6 .^{50}$

$$
\eta=\eta_{m} \eta_{p c} P_{f}
$$

$\eta_{m}$ is module efficiency which is given by equation $7 .^{51}$

$$
\eta_{m}=\eta_{r}\left[1-\beta\left(T_{c}-T_{r}\right)\right]
$$

$\eta_{r}$ is module reference efficiency, $\eta_{p c}$ is power conditioning efficiency, $P_{f}$ is power factor, $\beta$ is array efficiency, $T_{r}$ is reference temperature, $T_{c}$ is monthly average cell temperature, which can be calculated using equation 8 .

$$
T_{c}=T_{a}+\frac{\alpha \tau}{U_{L}} I_{T}
$$

where,

$$
\frac{U_{L}}{\alpha \tau}=\frac{I_{T, N O C T}}{\left(N O C T-T_{a, N O C T}\right)}
$$

$T_{a}$ is instantaneous ambient temperature, $N O C T$ is normal operating cell temperature, $I_{T, N O C T}=800 \mathrm{~W} / \mathrm{m}^{2}$ for a wind speed of $1 \mathrm{~m} / \mathrm{s}$. PV module performance is highly influenced by solar insolation and module temperature. A simplified model proposed by Zhou ${ }^{52}$ is presented below.

$$
\begin{gathered}
v_{o c}=\frac{V_{o c}}{n k T / q} \\
P_{\max }=\frac{\frac{V_{o c}}{n K T / q}-\ln \left(\frac{V_{o c}}{n K T / q}+0.72\right)}{1+\frac{V_{o c}}{n K T / q}} \cdot\left(1-\frac{R_{S}}{V_{O C} / I_{S C}}\right) \\
\frac{V_{o c o}}{1+\beta \ln \frac{G_{0}}{G}} \cdot\left(\frac{T_{0}}{T}\right)^{\gamma} \cdot I_{s c o}\left(\frac{G}{G_{o}}\right)^{\alpha}
\end{gathered}
$$


where $v_{o c}$ is normalized value of the open-circuit voltage $V_{o c}$ with respect to the thermal voltage $V_{t}=n k T / q, n$ is the ideality factor $(1<$ $n<2), T$ is the PV module temperature, $\alpha$ is the factor responsible for all the non-linear effects that the photocurrent depends on; $\beta$ is a $\mathrm{PV}$ module technology specific-related dimensionless coefficient and $\gamma$ is the factor considering all the non-linear temperature-voltage effects.

Above equation 11 represent the maximum power-output for a single PV module. For a real system, the voltage and current is usually scaled-up by connecting PV modules in series and parallel to tailor the PV array. The maximum power output of the PV array is given by equation 12 .

$$
P_{\text {array }}=N_{s} \times N_{p} \times P_{M}
$$

where $N_{s}, N_{p}$ and $P_{M}$ are PV modules in series, parallel and PV module power respectively.

\subsection{Wind Turbine Modeling}

Power output of wind turbine generator at a specific site depends on wind speed at hub height and speed characteristics of the turbine. Wind speed at hub height can be calculated by using power-law equation 13 .

$$
V_{z}=V_{i}\left[\frac{Z}{Z_{i}}\right]^{x}
$$

$V_{z}$ and $V_{i}$ are the wind speed at hub and reference height $Z$ and $Z_{i}$, and $x$ is a power law exponent which is a function of both the atmospheric stability in the layer over which $x$ is determined to be valid and the underlying surface characteristics. ${ }^{53}$ For e.g. $x$ is $1 / 7$ for open land. ${ }^{54}$

The fundamental equation governing the mechanical power output of the wind turbine is given by equation 14 .

$$
P_{\text {mech }}=\frac{1}{2} \rho A C_{p} V^{3}
$$

where $\rho$ is the air density $\left(\mathrm{kg} / \mathrm{m}^{3}\right), A$ is the swept area of the rotor blades $\left(\mathrm{m}^{2}\right), V$ is the velocity of wind $(\mathrm{m} / \mathrm{sec})$ and $C_{p}$ is the power coefficient of the wind turbine. The theoretical maximum value of the power coefficient $C_{p}$ is 0.593 , also known as Betz's coefficient. ${ }^{55}$ Which is often expressed as the function of the rotor tip-speed to windspeed ratio $(\lambda)$ given by equation 15 .

$$
\lambda=\frac{\omega R}{V}
$$

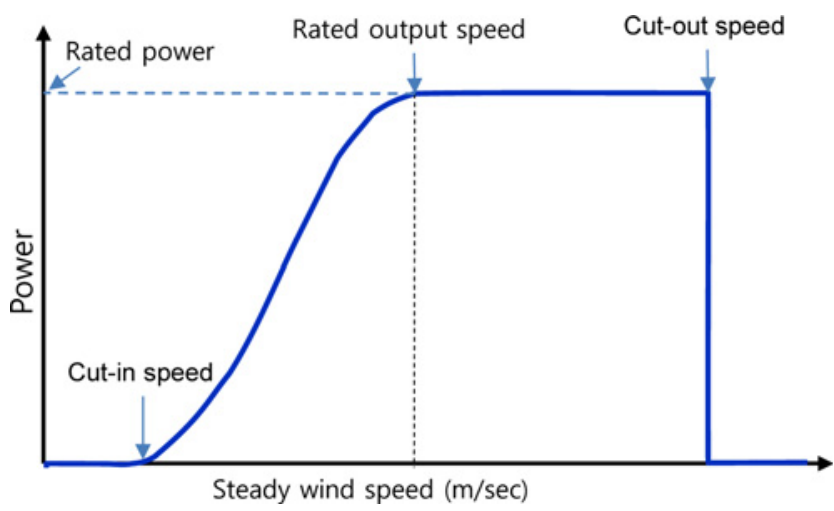

Fig. 11 Wind turbine power characteristics where $\omega$ is angular velocity $(\mathrm{rad} / \mathrm{sec})$ of turbine and $R$ is the turbine radius (m). Fig. 11 shows characteristics of power output from a wind turbine with steady wind speed.

Cut-in speed is a very low wind speed at which the turbine first starts to rotate and generate power. Cut-out speed is the high wind speed at which the forces on the turbine structure is high so that there is a risk of the damage to the rotor, to prevent damage, braking system is employed to bring the rotor to stand-still. Rated output speed is the wind speed between cut-in speed and cut-out speed where the power output reaches the maximum limit that the electrical generator is capable of and is called rated power output.

The mechanical energy trapped by the wind turbine blades is coupled with the electrical generator. Power output $P_{\text {wind }}\left(\mathrm{kW} / \mathrm{m}^{2}\right)$ from wind turbine generator can be calculated using equation 16 .

$$
P_{\text {Wind }}= \begin{cases}P_{R} \cdot \frac{v-v_{c}}{v_{R}-v_{c}} & \text { for }\left(v_{c} \leq v \leq v_{R}\right) \\ P_{R} & \text { for }\left(v_{R} \leq v \leq v_{F}\right) \\ 0 & \text { for }\left(v<v_{c} \text { or } v>v_{F}\right)\end{cases}
$$

where, $P_{R}$ is the rated electrical power, $v_{C}$ is the cut-in wind speed, $v_{R}$ is the rated wind speed, $v_{F}$ is the cut-off wind speed. The wind turbine performance calculations need to take into account the effects of wind turbine installation height. Actual power available from wind turbine can be calculated using equation 17 .

$$
P=P_{\text {Wind }} A_{\text {Wind }} \eta
$$

where $A_{\text {wind }}$ is the total swept area, and $\eta$ is efficiency of wind turbine generator and corresponding converters. ${ }^{56}$

\subsection{Engine Generator Modeling}

If the load requirements are higher than the generated power by renewable energy systems with battery bank, then load requirements should be met by operating back-up conventional generator like engine generator in HRES. An engine generator set can be divided into three main components: the prime mover, which includes an engine with a speed governor, the synchronous generator and the automatic voltage regulator. ${ }^{57}$

To determine rated capacity of the engine generator to be installed following guidelines must be followed. ${ }^{38}$

1. If the engine generator is directly connected to load, then the rated capacity of the generator must be at least equal to the maximum load.

2. If the engine generator is used as a battery charger, then the current produced by the generator should not be greater than $C_{A h} /$ $5 \mathrm{~A}$, where $C_{A h}$ is the ampere hour capacity of the battery. ElHefnawi $^{18}$ reported that generator operated at $70-90 \%$ of full load is economical.

\subsection{Modeling of Battery Bank and Its Performance}

Battery bank is a back-up energy storage system (for certain days known as days of autonomy) which is carefully sized to meet the load demand in the times of insufficient or unavailability of energy from the HRES. Days of autonomy might be as less as two days. Battery sizing depends on factors such as maximum depth of discharge, temperature 
correction, rated battery capacity and battery life. Required battery capacity in ampere hour can be calculated using equation $18 .^{58}$

$$
B_{r c}=\frac{E_{c} D_{s}}{D O D_{\max } \eta_{t}}
$$

where $E_{c}$ is the load in ampere hour (Ah), $D_{s}$ is the battery autonomy days, $D O D_{\max }$ is the maximum battery depth of discharge (for deep cycle battery maximum DOD is $80 \%$ ), $\eta_{t}$ is the temperature correction factor. When the total output of HRES is greater than the energy demand, the battery bank is in charging state otherwise in discharging state. The charge quantity of battery bank at the time $t$ can be calculate by using equation 19.59

$$
E_{B}(t)=E_{B}(t-1)(1-\sigma)+\left(\frac{E_{G A}(t)-E_{L}(t)}{\eta_{i n v}}\right) \eta_{b a t}
$$

where $E_{B}(t)$ and $E_{B}(t-1)$ are the charge quantities of battery bank at the time $t$ and $(t-1), E_{G A}(t)$ is the total energy generated by renewable energy source after energy loss in controller, $E_{L}(t)$ is load demand at the time $t, \eta_{i n v}$ and $h_{b a t}$ are the efficiency of inverter and charge efficiency of battery bank, $s$ is the self-discharge rate which depends on the accumulated charge and the state of battery health. Charge quantity of battery bank is subjected to the constraints as shown in equation 20 .

$$
E_{B_{\min }} \leq E_{B}(t) \leq E_{B_{\max }}
$$

where $E_{B_{\max }}$ and $E_{B_{\min }}$ are the maximum and minimum charge quantity of battery bank.

For HRES, most important battery characteristics are the battery lifetime, DOD, the maintenance requirements, state of charge (SOC) and the floating charge voltage. For optimization of the HRES, all these characteristics must be considered. However because of complexity in integrating all in optimization tool, SOC and the floating charge voltage were taken in consideration during optimization in ref. 60. To know the SOC of the battery at time $(t)$, the SOC at $(t-1)$, the charging and discharging time and the current should be known in advance. The SOC of the battery at time $(t)$ can be calculated using equation $21 .^{6}$

$$
\operatorname{SOC}(t)=\operatorname{SOC}(t-1) \cdot\left(1-\frac{\sigma . \Delta t}{24}\right)+\frac{I_{b a t}(t-1) \cdot \Delta t \cdot \eta_{b a t}}{C_{b a t}^{\prime}}
$$

where $C^{\prime}{ }_{b a t}$ is the nominal capacity of the battery, (Ah), and $\eta_{b a t}$ is the battery charging and discharging efficiency (usually round-off efficiency of charging and discharging efficiency).

\section{HRES Optimization Methods}

A well designed simulation program permits to determine the optimum size of battery bank, PV array, Wind turbine, Hydro generation capacity and other generation system for an autonomous or grid integrated HRES for a given load and a desired LPSP based on various criteria. Some of the criteria are minimum cost of the system, minimum capacity of system and storage devices, maximum power generation, and minimum LPSP and minimum LOLP.

Various optimization techniques such as graphical construction, ${ }^{54,62}$ probabilistic approach ${ }^{43}$ iterative technique, artificial intelligence (AI), dynamic programming, linear programming ${ }^{63,64}$ and multi-objective were used by researchers to optimize hybrid PV/wind energy system. Table 2 shows detail of optimization techniques used by various authors.

\subsection{Graphical Construction}

Problem with two design variables can be solved by observing graphically how they change with respect to one another. All constraint functions are plotted in the same chart. By visual inspection of the feasible region, the optimized point on the graph can be identified after objective function contours are drawn.

Markvart et al. ${ }^{65}$ used a long time series of solar radiation where the optimal sizing was determined by a superposition of contributions from climatic cycles of low daily solar radiation. Ai et al., ${ }^{59}$ presented method for optimum size of hybrid PV/wind energy system. Performance of hybrid PV/wind energy system was determined on hourly basis; by fixing the wind generators capacity. Annual LOLP with different capacity of PV array and battery bank were calculated

\begin{tabular}{|c|c|c|c|}
\hline Optimization techniques & Optimized elements & References & Remarks \\
\hline Graphical Construction & Battery and PV array & $54,62,65$ & Normally used for two parameters \\
\hline Probabilistic approach & Performance of hybrid-system & $43,66-69$ & Based on statistical approach of data collection \\
\hline Deterministic approach & Standalone PV with battery bank & 58,70 & $\begin{array}{l}\text { Using equations for determining specific values } \\
\text { using a constant parameters. }\end{array}$ \\
\hline $\begin{array}{l}\text { Iterative approach } \\
\text { a. Hill climbing } \\
\text { b. Dynamic Programming } \\
\text { c. Linear Programming } \\
\text { d. Multi objective } \\
\end{array}$ & Hybrid solar-wind system & $\begin{array}{c}63,71-74 \\
69 \\
75 \\
75,76 \\
\end{array}$ & $\begin{array}{l}\text { Based on LPSP to find possible combination of } \\
\text { solar-wind combination }\end{array}$ \\
\hline $\begin{array}{l}\text { Artificial Intelligence } \\
\text { a. Genetic Algorithm } \\
\text { b. Particle Swarm } \\
\text { c. Fuzzy Logic } \\
\text { d. Artificial Neural Network } \\
\text { e. Hybrid model } \\
\end{array}$ & $\begin{array}{l}\text { Hybrid solar-wind system with } \\
\text { battery bank }\end{array}$ & $\begin{array}{l}60,77-80 \\
81-84 \\
85 \\
25,86 \\
87 \\
\end{array}$ & Based on Evolution technique \\
\hline $\begin{array}{r}\text { Software based } \\
\text { a. HOMER }\end{array}$ & & $88-91$ & $\begin{array}{l}\text { Input file with all necessary information is supplied. } \\
\text { The software takes care of other things. }\end{array}$ \\
\hline
\end{tabular}
and optimum configuration (cost and LPSP) was found by drawing a tangent to the trade-off curve.

Table 2 Various optimization techniques 


\subsection{Probabilistic Approach}

In probability approach, randomness is present depending on the collected data thus variable states are not described by unique values, but rather using one of the statistical tools.

Optimum size of hybrid PV/wind energy system can be calculated on an hourly basis or daily average power per month, the day of minimum PV power per month, and the day of minimum wind power per month. Two advantages of this method are that the cost and time of environmental and load data collection are minimum.

\subsubsection{Hourly Average Generation Capacity Method}

In this method, the hourly average wind, insolation, and power demand are used for optimization of the system sizing. This calculation is based on the average annual monthly data of sun and the wind. The size of the photovoltaic and wind components is given by the following equations. ${ }^{63}$ The objective function $\left(F_{c}\right)$ which is to be minimized is given by equation 22 .

$$
F_{c}=C_{c}+C_{m}
$$

where $C_{c}$ is the capital cost and $C_{m}$ is the annual maintenance cost. In order to have good balance over a time, the difference $(\Delta P)$ between power generated $\left(P_{g e n}\right)$ and power demand $\left(P_{d e m}\right)$ should be minimum.

$$
\Delta P=P_{g e n}-P_{d e m}
$$

\subsubsection{Most Unfavorable Month Method}

In this method, the size of the PV and Wind generators is calculated in the most unfavorable month. The unfavorable irradiation month and unfavorable wind speed month are determined based on the available data. ${ }^{92,93}$ The size $A_{i}\left(\mathrm{~m}^{2}\right)$ of $\mathrm{PV}$ or wind component is given by equation 24 .

$$
A_{i}=\max \left(\frac{E_{L o a d, m}}{E_{i, m}}\right)
$$

where $m=1, \ldots, 12$ represents the month of the year, $E_{\text {Load }}$ is the load of particular month and $E_{i, m}$ is wither monthly energy produced by the system (PV or wind) per unit area. The total energy produced by the generators (PV, wind) and supplied to the load is expressed as equation 25-26.

$$
\begin{gathered}
\Sigma E_{i} A_{i}=E_{\text {Load }} \\
E_{i} \times A_{i}=f_{i} \times E_{\text {Load }}
\end{gathered}
$$

where $f_{i}$ is the fraction of the load supplied by the generator $(i)$.

\subsection{Deterministic Approach}

In deterministic approach, every set of variable states is uniquely determined by parameters in the model and by sets of previous states of these variables, thus there is always unique solution for given parameters, unlike probabilistic approach. Bhandari and Stadler ${ }^{70}$ calculated system size and cost for PV system installed in Nepal.

\subsection{Iterative Approach}

Iterative approach is a mathematical procedure generally performed using computer that generated a sequence of improving approximate solution for the optimization problem until a termination criteria is reached. As the number of optimization variables rises, the computation time increases exponentially when using this approach. $\mathrm{Li}$ et al. ${ }^{74}$ used this approach to optimize PV-wind-battery HRES based on the minimization of life cycle cost.

\subsection{Artificial Intelligence}

Artificial intelligence (AI) is the branch of computer science that studies and develops intelligent machines and software. Russell and Norvig ${ }^{94}$ define AI as "the study and design of intelligent agents" where an intelligent agent takes actions that maximize the chance of success.

AI consists of branches such as artificial neural networks (ANN), genetic algorithms (GA), fuzzy logic (FL) and hybrid systems combining two or more of the above branches. The appropriate use of intelligent technologies leads to useful systems with improved performance or other characteristics that cannot be achieved through traditional methods. ${ }^{95}$

\subsubsection{Optimization with Genetic Algorithm}

GA is a dynamic search technique used in computing to find true or approximate solutions for the optimization and search problems. GA are categorized as global search heuristics. GA are a particular class of evolutionary algorithms that use techniques inspired by evolutionary biology such as inheritance, mutation, selection and recombination.

A typical GA requires two things to be defined:

a. A genetic representation of the solution domain

b. A fitness function to evaluate the solution domain

GA might be useful in problem domains that have a complex fitness landscape that a traditional hill climbing algorithm might fail. The flow chart of the GA optimization process for HRES is illustrated in Fig. 12.

$\mathrm{Xu}$ et al. ${ }^{80}$ used GA with elitist strategy for optimally sizing a standalone hybrid PV/Wind power system for a year (8760 hours). Their main objectives were to minimize the total capital cost of the system with constrained LPSP.

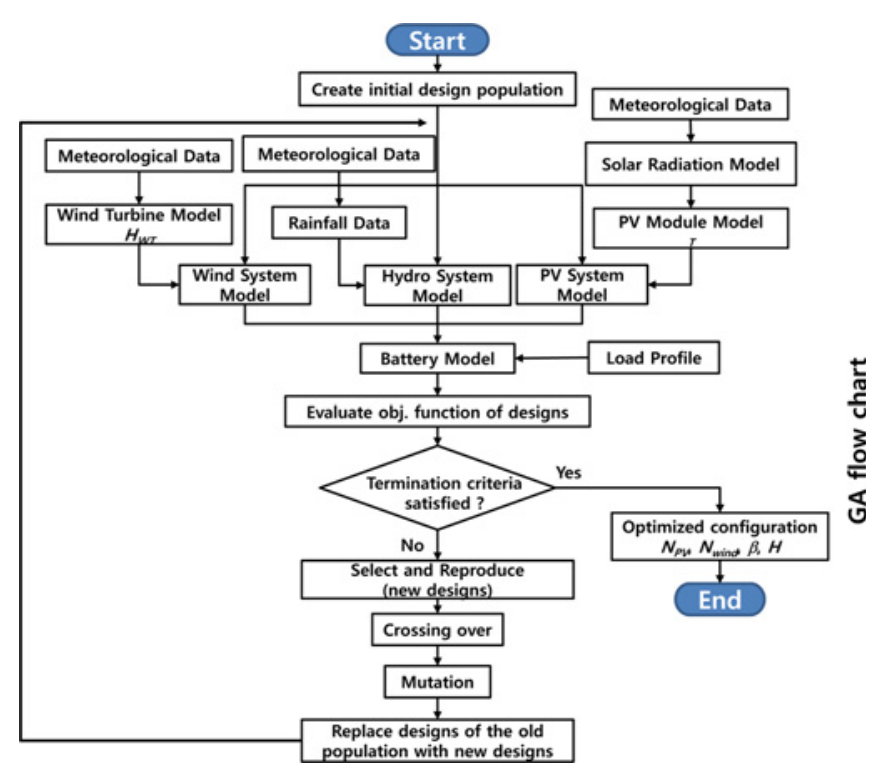

Fig. 12 Flow chart of typical Genetic algorithm consisting of PV-Wind and Hydro models 


\subsection{Software based Approach}

One of the popular commercial software for designing and analyzing hybrid power system is HOMER of National Renewable Energy Laboratory (NREL)/USA. Solar insolation, electrical load, hybrid generator technical details, costs, constraints, controls and type of dispatch strategy are used as the input to the HOMER software.

Hrayshat ${ }^{91}$ carried out a detailed techno-economic analysis using HOMER software to design an optimal hybrid PV-diesel-battery system for remote house in Jordan.

Further information regarding the optimizing methods used in HRES, detailed references for each type of optimization methods are listed in Table 2.

\section{Optimal Design Criteria for HRES}

HRES system sizing involves finding the cheapest combination of all generators size (renewable generator and conventional generator) and storage capacity that will meet the anticipated demand load with the minimum acceptable level of security. A number of design criteria based on economic, reliability, load etc. have been adopted by researchers for optimally designing HRES. The details of HRES optimal design criteria is listed in Table 3. In the following section, commonly used design criteria are briefly discussed.

\subsection{Cost of the Energy}

For a hybrid system, the life time of the plant is generally assumed to be 20 years and the battery bank is normally replaced every 5 years. The cost of the energy also depends on capital cost, operation \& maintenance costs, depreciation period and energy produced in one year, the potential down trend of equipment cost with rising volumes etc. A simple cost calculation relation is given by equation 27 .

$$
C_{E}=C_{C a p} \times \frac{R}{E_{T o t}}+C_{O \& M}
$$

where, $C_{E}$ is energy cost, $C_{C a p}$ is capital cost for HRES generator and storage device, $R$ is annual discount rate for capital costs, $E_{T o t}$ is total energy generated and $C_{O \& M}$ is annual operation and maintenance costs.

Number of researchers have extensively used cost of electricity generated as a deciding term to evaluate HRES configuration, at the predefined LOLP. The cost per $\mathrm{kWh}$ has been found useful for the

Table 3 Methods of sizing of hybrid systems

\begin{tabular}{|c|c|c|}
\hline Optimization based on & Objective Functi & References \\
\hline \multirow{3}{*}{ Economy } & Capital cost & 54,80 \\
\hline & $\begin{array}{c}\text { Annualized } \\
\text { cost of system }\end{array}$ & 73 \\
\hline & Operation & 75,96 \\
\hline \multirow{2}{*}{ Reliability } & LPSP & 60,80 \\
\hline & LOLP & 56 \\
\hline Techno-economic analysis & System cost & $35,60,91$ \\
\hline Yearly/monthly/ hourly average method & & 63 \\
\hline Most unfavorable month method & & 92,93 \\
\hline \multicolumn{3}{|l|}{ Load } \\
\hline $\begin{array}{l}\text { a. Constant Load } \\
\text { b. Variable Load }\end{array}$ & & $\begin{array}{c}60,80 \\
68\end{array}$ \\
\hline
\end{tabular}

evaluation of HRES. Cost of electricity per kWh is given by equation 28 .

$$
\operatorname{Cost} / k W h(\$)=\frac{C_{\text {Total }}}{E_{\text {Total }}(k W h)}
$$

where $C_{\text {Total }}$ is the total annual cost incurred to produce total annual electricity generation $E_{\text {Total }}$ in $\mathrm{kWh}$.

\subsection{Life Cycle Cost}

Whole-life-cost or life cycle cost (LCC) of HRES, refers to the total cost incurred over the productive life of the system. LCC have been used to decide economic feasibility of the system. The system with lowest LCC is always preferred. LCC is either calculated with or without accounting depreciation of the system using equation 29 and $30 .{ }^{16}$

$$
\begin{gathered}
P_{V}=\sum_{k=1}^{t} \frac{C_{t}}{(1+t)^{t}} \\
P_{V D}=(C+m)_{p v}+(C+m)_{\text {wind }}+(C+m)_{\text {battery }}+(C+m)_{\text {diesel }}-D
\end{gathered}
$$

where $P_{V}$ and $P_{V D}$ are present value of the system without and with depreciation respectively, $t$ is the time of analysis, $i$ is the interest rate per year, $C_{t}$ is the cost in year $t, m$ is the maintenance cost of the system, and $D$ is the present value of depreciation.

\subsection{Loss of Power Supply Probability (LPSP)}

This sizing method consists of determining the optimal number of the batteries, the photovoltaic modules, wind generator capacity and other renewable generator according to the optimization principle knowing the reliability of power supply. Reliability of power supply is based on the concept of the probability of loss of power supply from hybrid system that is unable to meet the load demand.

LPSP can be defined as the long-term average fraction of the loss that is not supplied by a power system. ${ }^{54}$ LPSP of 1 means that load is never satisfied while LPSP of 0 means that load is always satisfied. ${ }^{97}$

The methodology for LPSP can be summarized in two steps:

a. During the extra power generated from the HRES, the surplus power is used to charge the battery and new state of charge (SOC) is calculated until the battery capacity is full. Additional energy after full charge of battery is not used for productive work.

b. During the deficiency of power generated from HRES, energy stored in the battery is used to meet the demand load, and new SOC is calculated until the battery bank capacity drops to the minimum level until the hardware disconnects from the load.

In terms of SOC of batteries, the LPSP can be found using equation 31.

$$
L P S P=\operatorname{Pr}\left\{E_{B}(t) \leq E_{B_{\min }} ; \text { for } i \leq T\right\}
$$

i.e., the probability of the state of charge at any moment $t$, within the time period $T$, to be less or equal to the minimal level of the supplied energy in battery $E_{B m i n} . E_{B}(\mathrm{t})$ is the energy stored in the battery at any moment $(t)$.

\subsection{Loss of Load Probability}

Loss of load (LOL) is defined as the HRES inability to meet the 
daily peak load. A LOL occurs whenever the system load exceeds the available generating capacity. ${ }^{98}$ The overall probability that there will be a shortage of power (loss of power) is called loss of load probability (LOLP) which is expressed in terms of days per year, hours per day or percentage of time. The LOLP measure was first introduced by Calabrese. ${ }^{99}$ The LOLP is given by the following set of equations $32-34 .^{71}$

$$
L O L P=\frac{\sum_{t=1}^{n} \operatorname{hours}\left(I_{\text {supply }}<I_{\text {needed }}(t)\right)}{n}
$$

where

$$
\begin{gathered}
I_{\text {needed }}(t)=\frac{L(t)-P_{W}(t)-P_{P V}(t)}{V_{L}} \eta\left(I_{\text {battery }}(t)\right) \\
I_{\text {needed }}(t)=\min \left(I_{\max }=\frac{0.2 S O C}{\Delta t}, \frac{S O C(t) \sigma-S O C_{\min }}{\Delta t}\right)
\end{gathered}
$$

And $I_{\text {needed }}(\mathrm{t})$ is the current required for the load at hour $t, I_{\text {supply }}(\mathrm{t})$ is the current supplied by HRES at hour $t, n$ is number of samples. $V_{L}$ is the nominal voltage needed by the system, $L(\mathrm{t})$ is the electrical load requirements at hour $t, P_{W}(t)$ is the power generated by the wind turbine at hour $t$, and $P_{P V}(t)$ is the power generated by PV modules at hour $t$. If LOLP is low then it results in high cost of the system and vice versa.

\section{Conclusions}

HRES is increasingly being popular for remote and rural electrification because of lower cost of PV and wind generator in recent years. It is thought that it will be instrumental for providing electricity to majority of 1 billion population who are deprived of electricity mostly in developing countries. Instead of single generation system like PV or Wind, HRES can harvest energy even when potential of one is minimal, which increases power reliability.

Current global energy scenario and in particular the contribution of renewable energies has been systematically included in the paper. A concise mathematical model of several generators and battery bank has been presented. A comprehensive review of optimization of hybrid power system consisting of renewable sources is explained in detail. Several optimization methods and optimization design criteria are explained with their strength.

The review carried out in this paper gives a concise yet reasonably good idea about the tools that researchers have been using for several decades for optimizing the HRES either grid - tied or not. Furthermore, the inclusion of scope diagram for easy visualization of the contents of the paper gives a clear visualization of the contents of the paper. The two tables with the details of optimization techniques and optimization of HRES based on several important criteria come handy for all the researchers and academics.

\section{ACKNOWLEDGEMENT}

This work was supported by grants from the National Research Foundation of Korea (NRF), funded by the Korean government (MSIP) (No. 2011K1A5A2000071, 2012K1A3A9A01027846), and by cluster projects in the Engineering Research Institute, College of Engineering of Seoul National University.

\section{REFERENCES}

1. Enslin, J., "Renewable Energy as an Economic Energy Source for Remote Areas," Renewable Energy, Vol. 1, No. 2, pp. 243-248, 1991.

2. Bhandari, B., Lee, K.-T., Cho, Y.-M., Lee, C. S., Song, C.-K., et al., "Hybridization of Multiple Renewable Power Sources for Remote Village Electrification," Proc. of the International Symposium on Green Manufacturing and Applications, 2013.

3. Bhandari, B., Lee, K.-T., Lee, C. S., Song, C.-K., Maskey, R. K., et al., "A Novel Off-Grid Hybrid Power System Comprised of Solar Photovoltaic, Wind, and Hydro Energy Sources," Applied Energy, Vol. 133, pp. 236-242, 2014.

4. Ahn, S., Lee, K., Bhandari, B., Lee, G., Lee, C., et al., "Formation Strategy of Renewable Energy Sources for High Mountain Off-Grid System Considering Sustainability," J. Korean Soc. Precis. Eng., Vol. 29, No. 9, pp. 958-963, 2012.

5. U.S. Energy Information Administration, "International Energy Outlook 2011,” http://www.eia.gov/forecasts/archive/ieo11/ (Accessed 12 December 2014)

6. U.S. Energy Information Administration, "Annual Energy Outlook 2012 Early Release,” http://www.eia.gov/forecasts/aeo/er/pdf/ 0383er(2012).pdf (Accessed 12 December 2014)

7. Wang, C., "Modeling and Control of Hybrid Wind/Photovoltaic/Fuel Cell Distributed Generation Systems," Ph.D. Thesis, Department of Electrical and Computer Engineering, Montant State University, 2006.

8. U.S. Energy Information Administration, "Electric Power Monthly," http://www.eia.gov/energy_in_brief/article/renewable_electricity.cfm (Accessed 12 December 2014)

9. European Photovoltaic Industry Association, "Global Market Outlook for Photovoltaics 2013-2017," http://www.epia.org/ fileadmin/user_upload/Publications/GMO_2013 _ _Final_PDF.pdf (Accessed 12 December 2014)

10. GWEC, "Global Wind Report - Annual Market Update 2012,” 2013.

11. Renewable Energy Policy Network for the 21st Century, "Renewables 2013 Global Status Report," 2013.

12. Kaundinya, D. P., Balachandra, P., and Ravindranath, N., "GridConnected Versus Stand-Alone Energy Systems for Decentralized Power-A Review of Literature," Renewable and Sustainable Energy Reviews, Vol. 13, No. 8, pp. 2041-2050, 2009.

13. First Solar, "World's Largest Operational Solar PV Project, Agua Caliente, Achieves 250 Megawatts of Grid-Connected Power," http:/ /investor.firstsolar.com/releasedetail.cfm?ReleaseID $=706034$

(Accessed 12 December 2014) 
14. Solar Energy Industries Association, "NRG Energy Completes 250 MW California Valley Solar Ranch," http://www.seia.org/news/nrgenergy-completes-250-mw-california-valley-solar-ranch (Accessed 12 December 2014)

15. Feldman, D., Barbose, G., Margolis, R., Wiser, R., Darghouth, N., et al., "Photovoltaic (PV) Pricing Trends: Historical, Recent, and NearTerm Projections," National Renewable Energy Laboratory \& Lawrence Berkeley National Laboratory, 2012.

16. Valente, L. C. G. and de Almeida, S. C. A. B., "Economic Analysis of a Diesel/Photovoltaic Hybrid System for Decentralized Power Generation in Northern Brazil," Energy, Vol. 23, No. 4, pp. 317-323, 1998.

17. Muselli, M., Notton, G., Poggi, P., and Louche, A., "PV-Hybrid Power Systems Sizing Incorporating Battery Storage: An Analysis via Simulation Calculations," Renewable Energy, Vol. 20, No. 1, pp. $1-7,2000$.

18. El-Hefnawi, S. H., "Photovoltaic Diesel-Generator Hybrid Power System Sizing," Renewable Energy, Vol. 13, No. 1, pp. 33-40, 1998.

19. Shrestha, G. and Goel, L., "A Study on Optimal Sizing of StandAlone Photovoltaic Stations," IEEE Transactions on Energy Conversion, Vol. 13, No. 4, pp. 373-378, 1998.

20. Abouzahr, I. and Ramakumar, R., "Loss of Power Supply Probability of Stand-Alone Photovoltaic Systems: A Closed Form Solution Approach," IEEE Transactions on Energy Conversion, Vol. 6, No. 1, pp. 1-11, 1991.

21. Egido, M. and Lorenzo, E., "The Sizing of Stand Alone PV-System: A Review and a Proposed New Method," Solar Energy Materials and Solar Cells, Vol. 26, No. 1, pp. 51-69, 1992.

22. Ru, Y., Kleissl, J., and Martinez, S., "Storage Size Determination for Grid-Connected Photovoltaic Systems," IEEE Transactions on Sustainable Energy, Vol. 4, No. 1, pp. 68-81, 2013.

23. Price, T. J., “James Blyth-Britain's First Modern Wind Power Pioneer," Wind Engineering, Vol. 29, No. 3, pp. 191-200, 2005.

24. Feijoo, A. E., Cidras, J., and Dornelas, J. G., "Wind Speed Simulation in Wind Farms for Steady-State Security Assessment of Electrical Power Systems," IEEE Transactions on Energy Conversion, Vol. 14, No. 4, pp. 1582-1588, 1999.

25. Li, S., Wunsch, D. C., O'Hair, E., and Giesselmann, M. G., "Comparative Analysis of Regression and Artificial Neural Network Models for Wind Turbine Power Curve Estimation," Journal of Solar Energy Engineering, Vol. 123, No. 4, pp. 327-332, 2001.

26. Salameh, Z. M. and Safari, I., "The Effect of the Windmill's Parameters on the Capacity Factor," IEEE Transactions on Energy Conversion, Vol. 10, No. 4, pp. 747-751, 1995.

27. Boccard, N., "Capacity Factor of Wind Power Realized Values vs. Estimates,” Energy Policy, Vol. 37, No. 7, pp. 2679-2688, 2009.

28. Celik, A. N., "A Simplified Model for Estimating the Monthly Performance of Autonomous Wind Energy Systems with Battery Storage," Renewable Energy, Vol. 28, No. 4, pp. 561-572, 2003.
29. Celik, A. N., "A Simplified Model for Estimating Yearly Wind Fraction in Hybrid-Wind Energy Systems," Renewable Energy, Vol. 31, No. 1, pp. 105-118, 2006.

30. Abouzahr, I. and Ramakumar, R., "Loss of Power Supply Probability of Stand-Alone Wind Electric Conversion Systems: A Closed Form Solution Approach,", IEEE Transactions on Energy Conversion, Vol. 5, No. 3, pp. 445-452, 1990.

31. Karki, R. and Billinton, R., "Cost-Effective Wind Energy Utilization for Reliable Power Supply," IEEE Transactions on Energy Conversion, Vol. 19, No. 2, pp. 435-440, 2004.

32. Office of Energy Efficiency \& Renewable Energy, "History of Hydropower," http://www1.eere.energy.gov/water/hydro history.html (Accessed 12 December 2014)

33. Earth Policy Institute, "Hydropower Continues Steady Growth," http://www.earth-policy.org/data_highlights/2012/highlights29

(Accessed 12 December 2014)

34. Earth Policy Institute, "Data Highlights," http://www.earth-policy.org/ data_highlights/2012/highlights29 (Accessed 12 December 2014)

35. Bifano, W. J., Ratajczak, A. F., Bahr, D. M., and Garrett, B. G., "Social and Economic Impact of Solar Electricity at Schuchuli Village," Solar Technology in Rural Settings: Assessments of Field Experiences, 1979.

36. Nehrir, M. H., LaMeres, B. J., Venkataramanan, G., Gerez, V., and Alvarado, L., "An Approach to Evaluate the General Performance of Stand-Alone Wind/Photovoltaic Generating Systems," IEEE Transactions on Energy Conversion, Vol. 15, No. 4, pp. 433-439, 2000.

37. Lim, J. H., "Optimal Combination and Sizing of a New and Renewable Hybrid Generation System," International Journal of Future Generation Communication and Networking, Vol. 5, No. 2, pp. 43-59, 2012.

38. Notton, G., Muselli, M., and Louche, A., "Autonomous Hybrid Photovoltaic Power Plant using a Back-Up Generator: A Case Study in a Mediterranean Island," Renewable Energy, Vol. 7, No. 4, pp. 371-391, 1996.

39. Elhadidy, M. and Shaahid, S., "Parametric Study of Hybrid (Wind+Solar+Diesel) Power Generating Systems," Renewable Energy, Vol. 21, No. 2, pp. 129-139, 2000.

40. Chedid, R., Akiki, H., and Rahman, S., "A Decision Support Technique for the Design of Hybrid Solar-Wind Power Systems," IEEE Transactions on Energy Conversion, Vol. 13, No. 1, pp. 76-83, 1998.

41. United Nations, "Decade Of Sustainable Energy For All," http:// www.un.org/News/Press/docs/2012/ga11333.doc.htm (Accessed 12 December 2014)

42. Bhandari, B., Poudel, S. R., Lee, K.-T., and Ahn, S.-H., "Mathematical Modeling of Hybrid Renewable Energy System: A Review on Small Hydro-Solar-Wind Power Generation," Int. J. Precis. Eng. Manuf.-Green Tech., Vol. 1, No. 2, pp. 157-173, 2014. 
43. Karaki, S., Chedid, R., and Ramadan, R., "Probabilistic Performance Assessment of Autonomous Solar-Wind Energy Conversion Systems," IEEE Transactions on Energy Conversion,, Vol. 14, No. 3, pp. 766-772, 1999.

44. Chouder, A., Silvestre, S., Sadaoui, N., and Rahmani, L., "Modeling and Simulation of a Grid Connected PV System based on the Evaluation of Main PV Module Parameters," Simulation Modelling Practice and Theory, Vol. 20, No. 1, pp. 46-58, 2012.

45. Das, D., Esmaili, R., Xu, L., and Nichols, D., “An Optimal Design of a Grid Connected Hybrid Wind/Photovoltaic/Fuel Cell System for Distributed Energy Production,” Proc. of the IEEE on Industrial Electronics Society, p. 6, 2005.

46. De Soto, W., Klein, S., and Beckman, W., "Improvement and Validation of a Model for Photovoltaic Array Performance," Solar Energy, Vol. 80, No. 1, pp. 78-88, 2006.

47. Salam, Z., Ishaque, K., and Taheri, H., “An Improved Two-Diode Photovoltaic (PV) Model for PV System," Proc. of the Power Electronics, Drives and Energy Systems (PEDES) \& 2010 Power India, pp. 1-5, 2010.

48. Duffie, J. A. and Beckman, W. A., "Solar Engineering of Thermal Process," Wiley \& Sons, 1991.

49. Markvart, T., "Solar Electricity,” John Wiley \& Sons, 2000.

50. Habib, M. A., Said, S. A. M., El-Hadidy, M. A., and Al-Zaharna, I., "Optimization Procedure of a Hybrid Photovoltaic Wind Energy System,” Energy, Vol. 24, pp. 919-929, 1999.

51. Evans, D., "Simplified Method for Predicting Photovoltaic Array Output," Solar Energy, Vol. 27, No. 6, pp. 555-560, 1981.

52. Zhou, W., Yang, H., and Fang, Z., "A Novel Model for Photovoltaic Array Performance Prediction," Applied Energy, Vol. 84, No. 12, pp. 1187-1198, 2007.

53. Hsu, S., Meindl, E. A., and Gilhousen, D. B., "Determining the Power-Law Wind-Profile Exponent under Near-Neutral Stability Conditions at Sea," Journal of Applied Meteorology, Vol. 33, No. 6, pp. 757-765, 1994.

54. Borowy, B. S. and Salameh, Z. M., "Methodology for Optimally Sizing the Combination of a Battery Bank and PV Array in a Wind/ PV Hybrid System," IEEE Transactions on Energy Conversion, Vol. 11, No. 2, pp. 367-375, 1996.

55. Betz, A., "Introduction to the Theory of Flow Machines," Pergamon, 1966.

56. Deshmukh, M. and Deshmukh, S., "Modeling of Hybrid Renewable Energy Systems," Renewable and Sustainable Energy Reviews, Vol. 12, No. 1, pp. 235-249, 2008.

57. Theubou, T., Wamkeue, R., and Kamwa, I., "Dynamic Model of Diesel Generator Set for Hybrid Wind-Diesel Small Grids Applications," Proc. of the IEEE on Electrical \& Computer Engineering, pp. 1-4, 2012.
58. Bhuiyan, M. and Ali, A. M., "Sizing of a Stand-Alone Photovoltaic Power System at Dhaka," Renewable Energy, Vol. 28, No. 6, pp. 929-938, 2003.

59. Ai, B., Yang, H., Shen, H., and Liao, X., "Computer-Aided Design of PV/Wind Hybrid System," Renewable Energy, Vol. 28, No. 10, pp. 1491-1512, 2003.

60. Yang, H., Wei, Z., and Chengzhi, L., "Optimal Design and TechnoEconomic Analysis of a Hybrid Solar-Wind Power Generation System," Applied Energy, Vol. 86, No. 2, pp. 163-169, 2009.

61. Guasch, D. and Silvestre, S., "Dynamic Battery Model for Photovoltaic Applications," Progress in Photovoltaics: Research and Applications, Vol. 11, No. 3, pp. 193-206, 2003.

62. Markvart, T., "Sizing of Hybrid Photovoltaic-Wind Energy Systems,” Solar Energy, Vol. 57, No. 4, pp. 277-281, 1996.

63. Kellogg, W., Nehrir, M., Venkataramanan, G., and Gerez, V., "Optimal unit Sizing for a Hybrid Wind/Photovoltaic Generating System," Electric Power Systems Research, Vol. 39, No. 1, pp. 3538, 1996.

64. Chedid, R. and Saliba, Y., "Optimization and Control of Autonomous Renewable Energy Systems," International Journal of Energy Research, Vol. 20, No. 7, pp. 609-624, 1996.

65. Markvart, T., Fragaki, A., and Ross, J., "PV System Sizing using Observed Time Series of Solar Radiation," Solar Energy, Vol. 80, No. 1, pp. 46-50, 2006.

66. Tina, G., Gagliano, S., and Raiti, S., "Hybrid Solar/Wind Power System Probabilistic Modelling for Long-Term Performance Assessment," Solar Energy, Vol. 80, No. 5, pp. 578-588, 2006.

67. Bagul, A., Salameh, Z., and Borowy, B., "Sizing of a Stand-Alone Hybrid Wind-Photovoltaic System using a Three-Event Probability Density Approximation,” Solar Energy, Vol. 56, No. 4, pp. 323-335, 1996.

68. Posadillo, R. and López Luque, R., "Approaches for Developing a Sizing Method for Stand-Alone PV Systems with Variable Demand," Renewable Energy, Vol. 33, No. 5, pp. 1037-1048, 2008.

69. De, A. R. and Musgrove, L., "The Optimization of Hybrid Energy Conversion Systems using the Dynamic Programming ModelRapsody," International Journal of Energy Research, Vol. 12, No. 3, pp. 447-457, 1988.

70. Bhandari, R. and Stadler, I., "Electrification using Solar Photovoltaic Systems in Nepal," Applied Energy, Vol. 88, No. 2, pp. 458-465, 2011.

71. Yang, H., Lu, L., and Burnett, J., "Weather Data and Probability Analysis of Hybrid Photovoltaic-Wind Power Generation Systems in Hong Kong,” Renewable Energy, Vol. 28, No. 11, pp. 1813-1824, 2003.

72. Yang, H., Lu, L., and Zhou, W., "A Novel Optimization Sizing Model for Hybrid Solar-Wind Power Generation System," Solar Energy, Vol. 81, No. 1, pp. 76-84, 2007. 
73. Kellogg, W., Nehrir, M., Venkataramanan, G., and Gerez, V., "Generation Unit Sizing and Cost Analysis for Stand-Alone Wind, Photovoltaic, and Hybrid Wind/PV Systems," IEEE Transactions on Energy Conversion, Vol. 13, No. 1, pp. 70-75, 1998.

74. Li, J., Wei, W., and Xiang, J., "A Simple Sizing Algorithm for Stand-Alone PV/Wind/Battery Hybrid Microgrids," Energies, Vol. 5, No. 12, pp. 5307-5323, 2012.

75. Chedid, R. and Rahman, S., "Unit Sizing and Control of Hybrid Wind-Solar Power Systems," IEEE Transactions on Energy Conversion, Vol. 12, No. 1, pp. 79-85, 1997.

76. Chedid, R., Karaki, S., and Rifai, A., "A Multi-Objective Design Methodology for Hybrid Renewable Energy Systems," Proc. of the IEEE on Power Tech, pp. 1-6, 2005.

77. Yang, H., Zhou, W., Lu, L., and Fang, Z., "Optimal Sizing Method for Stand-Alone Hybrid Solar-Wind System with LPSP Technology by Using Genetic Algorithm," Solar Energy, Vol. 82, No. 4, pp. 354367,2008 .

78. Koutroulis, E., Kolokotsa, D., Potirakis, A., and Kalaitzakis, K., "Methodology for Optimal Sizing of Stand-Alone Photovoltaic/ Wind-Generator Systems using Genetic Algorithms," Solar Energy, Vol. 80, No. 9, pp. 1072-1088, 2006.

79. Mohammadi, M., Hosseinian, S., and Gharehpetian, G., "Ga-Based Optimal Sizing of Microgrid and DG Units under Pool and Hybrid Electricity Markets," International Journal of Electrical Power \& Energy Systems, Vol. 35, No. 1, pp. 83-92, 2012.

80. Xu, D., Kang, L., Chang, L., and Cao, B., "Optimal Sizing of Standalone Hybrid Wind/PV Power Systems using Genetic Algorithms," Proc. of the IEEE on Electrical and Computer Engineering, pp. 1722-1725, 2005.

81. Hakimi, S. and Moghaddas-Tafreshi, S., "Optimal Sizing of a StandAlone Hybrid Power System via Particle Swarm Optimization for Kahnouj Area in South-East of Iran,” Renewable Energy, Vol. 34, No. 7, pp. 1855-1862, 2009.

82. Boonbumroong, U., Pratinthong, N., Thepa, S., Jivacate, C., and Pridasawas, W., "Particle Swarm Optimization for AC-Coupling Stand Alone Hybrid Power Systems," Solar Energy, Vol. 85, No. 3, pp. 560-569, 2011.

83. Mohammadi, M., Hosseinian, S., and Gharehpetian, G., "Optimization of Hybrid Solar Energy Sources/Wind Turbine Systems Integrated to Utility Grids as Microgrid (MG) under Pool/ Bilateral/Hybrid Electricity Market using PSO," Solar Energy, Vol. 86, No. 1, pp. 112-125, 2012.

84. Kashefi, K. A., Riahy, G., and Kouhsari, S., "Optimal Design of a Reliable Hydrogen-Based Stand-Alone Wind/PV Generating System, Considering Component Outages," Renewable Energy, Vol. 34, No. 11, pp. 2380-2390, 2009.

85. La, T. G., Salvina, G., and Tina, G., "Optimal Sizing Procedure for Hybrid Solar Wind Power Systems by Fuzzy Logic," Proc. of the IEEE on Electrotechnical Conference, pp. 865-868, 2006.
86. Vosen, S. and Keller, J., "Hybrid Energy Storage Systems for StandAlone Electric Power Systems: Optimization of System Performance and Cost through Control Strategies," International Journal of Hydrogen Energy, Vol. 24, No. 12, pp. 1139-1156, 1999.

87. Khatib, T., Mohamed, A., and Sopian, K., "Optimization of a PV/ Wind Micro-Grid for Rural Housing Electrification using a Hybrid Iterative/Genetic Algorithm: Case Study of Kuala Terengganu, Malaysia," Energy and Buildings, Vol. 47, pp. 321-331, 2012.

88. Anayochukwu, A. V. and Nnene, E. A., "Simulation and Optimization of Photovoltaic/Diesel Hybrid Power Generation Systems for Health Service Facilities in Rural Environments," Electronic Journal of Energy \& Environment, Vol. 1, No. 1, pp. 57$70,2013$.

89. Nfah, E., Ngundam, J., Vandenbergh, M., and Schmid, J., "Simulation of Off-Grid Generation Options for Remote Villages in Cameroon," Renewable Energy, Vol. 33, No. 5, pp. 1064-1072, 2008.

90. Lal, D. K., Dash, B. B., and Akella, A., "Optimization of PV/Wind/ Micro-Hydro/Diesel Hybrid Power System in Homer for the Study Area," International Journal on Electrical Engineering and Informatics, Vol. 3, No. 3, pp. 307-325, 2011.

91. Hrayshat, E. S., "Techno-Economic Analysis of Autonomous Hybrid Photovoltaic-Diesel-Battery System," Energy for Sustainable Development, Vol. 13, No. 3, pp. 143-150, 2009.

92. El-Khadimi, A., Bchir, L., and Zeroual, A., "Dimensionnement et Optimisation Technico-Economique D'un Système D'Energie Hybride Photovoltaïque-Eolien Avec Système de Stockage," Revue des Énergies Renouvelables, Vol. 7, pp. 73-83, 2004.

93. Kusakana, K. and Vermaak, H. J., "Hybrid Renewable Power Systems for Mobile Telephony Base Stations in Developing Countries," Renewable Energy, Vol. 51, pp. 419-425, 2013.

94. Russell, S. J. and Norvig, P., "Artificial Intelligence: A Modern Approach,” $2^{\text {nd }}$ Ed., Upper Saddle River, 2003.

95. Liu, B. Y. and Jordan, R. C., "The Long-Term Average Performance of Flat-Plate Solar-Energy Collectors: With Design Data for the Us, Its Outlying Possessions and Canada," Solar Energy, Vol. 7, No. 2, pp. 53-74, 1963.

96. Ashok, S., "Optimised Model for Community-Based Hybrid Energy System,” Renewable Energy, Vol. 32, No. 7, pp. 1155-1164, 2007.

97. Chapman, R. N., "Sizing Handbook for Stand-Alone Photovoltaic/ Storage Systems." Sandia National Laboratories, 1987.

98. Pillai, N. V., "Loss of Load Probability of a Power System," Munich Personal Repec Archive, Paper No. 6953, 2008.

99. Calabrese, G., "Generating Reserve Capacity Determined by the Probability Method," Transactions of the American Institute of Electrical Engineers, Vol. 66, No. 1, pp. 1439-1450, 1947. 